\title{
SEJARAH DAN PERKEMBANGAN AMALAN PEMBAHAGIAN HARTA SEPENCARIAN DALAM MASYARAKAT ISLAM DI MALAYSIA (History and Development of Harta Sepencarian Distribution Practice in Muslims Society in Malaysia)
}

\author{
Mohd Norhusairi Mat Hussin* \& Mohd Zaidi Daud ${ }^{* *}$
}

\begin{abstract}
Abstrak
Harta Sepencarian merupakan amalan yang telah diamalkan sekian lama oleh masyarakat Melayu. Malah, amalan ini seiring dengan kewujudan adat dalam masyarakat Melayu khususnya Adat Perpatih dan Adat Temenggung. Adat pula adalah sesuatu yang tidak dapat dipisahkan dalam kajian sejarah khususnya apabila melibatkan asal usul sesuatu amalan dalam sesebuah masyarakat. Maka, artikel ini akan mengupas amalan pembahagian harta sepencarian dan perkembangannya dalam masyarakat Melayu menurut sejarah adat. Artikel ini sepenuhnya menggunakan kajian kepustakaan sebagai metode pengumpulan data dan seterusnya dianalisis melalui analisis kandungan secara bertema dalam meneliti aspek amalan harta sepencarian yang berlaku dalam masyarakat Melayu. Beberapa kes harta sepencarian yang pernah diputuskan oleh Mahkamah juga dijadikan contoh sebagai bukti yang menunjukkan amalan harta sepencarian ini telah diterima dan diamalkan dalam kalangan masyarakat Melayu sejak dahulu lagi selain sokongan penulisan akademik yang lain. Oleh itu, artikel ini mendapati bahawa amalan pembahagian harta sepencarian adalah bukan sesuatu yang baharu, bahkan ia telah menjadi sebahagian sejarah adat resam orang Melayu bukan sahaja di Malaysia bahkan di Nusantara Melayu khususnya di Asia Tenggara. Harta Sepencarian yang berasaskan adat tempatan orang Melayu ini telah diiktiraf oleh hukum syarak dan perundangan di Malaysia sememangnya mempunyai keunikan serta identiti yang tersendiri.
\end{abstract}

Kata kunci: Harta Sepencarian, Adat Melayu, Undang-Undang Adat Melayu, Adat Perpatih, Adat Temenggung, Melayu Nusantara

\begin{abstract}
Harta Sepencarian (jointly acquired property) has been practiced for decades by the Malay society. In fact, this practice is in line with the existence of Malay custom especially Adat Perpatih and Adat Temenggung. Customs is something that can never be separated from historical studies, particularly when it involves the origin of matters in a society. Hence, this article explored the practice of the harta sepencarian (jointly acquired property) and its development according to the history of Malay custom. This article used library research as a method of data collection and was then analyzed through thematic content analysis. All this method applied in researching aspects of harta sepencarian (jointly acquired property) practice in the society. In addition to other academic writing, some examples of cases that had been decided by the Court also has been elaborated to show evidence that the practice of harta sepencarian (jointly acquired property) has been accepted and practiced by the community over the years. Therefore, this study found that the practice of Harta Sepencarian (jointly acquired property) is not something new, but it has been part of the Malay customs history not only in Malaysia but also in Malay Archipelago, mainly in Southeast Asia. Besides that, Harta Sepencarian (jointly acquired property) which was associated with Malay custom and is now recognized by Islamic law and Malaysia's jurisprudence surely has its own uniqueness and identity.
\end{abstract}

Keywords: Harta Sepencarian, Malay Custom, Malay Customary Law, Adat Perpatih (Matrilineal Custom), Adat Temenggung, Malay Archipelago

\footnotetext{
* Mohd Norhusairi Mat Hussin, Senior Lecturer, Department of Shariah and Law, Academy of Islamic Studies, Universiti Malaya, Kuala Lumpur. E-mail: husairi@um.edu.my.

${ }_{* *}^{*}$ Mohd Zaidi Daud (Corresponding Author), Senior Lecturer, Department of Shariah and Law, Academy of Islamic Studies, Universiti Malaya, Kuala Lumpur. E-mel: zaididaud@um.edu.my.
} 


\section{Pendahuluan}

Sejarah telah menunjukkan adat merupakan amalan setempat dalam mempraktiskan gaya hidup serta sosial sesebuah masyarakat. Adat memainkan peranan penting dalam mengatur gerak geri dan perlakuan individu serta komuniti agar lebih terpandu. Sejarah masyarakat Melayu umpamanya terkenal dengan adat resam, pantang larang dan petua-petua yang diwarisi dari generasi ke generasi sebagai panduan. Namun setelah kehadiran Islam di rantau ini telah membawa kepada perubahan dalam kehidupan masyarakat Melayu daripada pelbagai aspek seperti bahasa, adat istiadat dan lainlain yang akhirnya membentuk identiti dan keunikan tersendiri walaupun terdapat pengaruh luaran lain seperti Hindu dan Barat. Seiring dengan perkembangan masa dan zaman, adat resam yang pada mulanya berasaskan kepada aturan secara lisan kemudiannya telah menjadi satu bentuk peraturan secara bertulis. Proses transformasi yang berlaku dalam masyarakat yang berasaskan adat dan seterusnya kepada satu bentuk peraturan yang lebih tersusun menunjukkan sinergi yang begitu harmoni dalam menjadikan sesebuah masyarakat itu bertamadun. Di Tanah Melayu umpamanya walaupun bukan semua adat dijadikan sebagai satu undang-undang namun terdapat beberapa aspek yang telah diperundangkan. Maka, lahirlah undang-undang adat Melayu sebagai suatu bentuk peraturan yang disusun berasaskan adat istiadat, nilai, norma, moral atau adab yang menjadi amalan hidup zaman kesultanan Melayu sebagai panduan serta kawalan kepada raja dan pembesar dalam melaksanakan proses pemerintahan negara. Undang-undang adat tersebut meliputi undang-undang di daratan (seperti UndangUndang Melaka dan Undang-Undang Kedah) dan undang-undang di lautan (seperti Undang-Undang Laut Melaka dan Undang-Undang Pelabuhan Kedah). ${ }^{1}$

Harta sepencarian adalah sebahagian daripada adat masyarakat Melayu yang bukan sahaja diterima di Malaysia bahkan Nusantara amnya. Uniknya, konsep harta sepencarian ini hanya boleh ditemui secara langsung dalam adat masyarakat Melayu Nusantara. Bahkan kajian juga menunjukkan bahawa masyarakat peribumi yang bukan Muslim khususnya di Sabah dan Sarawak juga mengamalkan konsep pembahagian yang sama. ${ }^{2}$ Ini bererti, konsep pembahagian harta perkahwinan menerusi harta sepencarian yang diamalkan oleh kebanyakan penduduk Melayu Nusantara adalah berbeza dengan pengamalan harta perkahwinan yang diamalkan di negara-negara lain di dunia seperti Mesir, Australia dan United Kingdom. ${ }^{3}$ Amalan harta sepencarian ini telah diamalkan dalam kedua-dua adat orang Melayu iaitu Adat Temenggung dan Adat Perpatih. Malah kedua-dua adat ini khususnya adat Perpatih telah diamalkan sekian lama dan jauh lebih awal daripada common law Inggeris sendiri. ${ }^{4}$

Praktis pembahagian harta perkahwinan melalui harta sepencarian adalah satu bentuk pembahagian harta yang diperoleh oleh suami dan isteri dalam sesebuah perkahwinan. Harta sepencarian dikategorikan sebagai harta yang dikumpulkan secara bersama oleh suami dan isteri dalam sesuatu tempoh perkahwinan meliputi harta alih seperti wang ringgit, barang kemas, kenderaan dan seumpamanya dan juga harta tidak alih seperti rumah, kereta dan sebagainya. Harta-harta tersebut biasanya dikumpulkan secara usaha bersama di antara suami isteri dalam tempoh perkahwinan sama ada wujud usaha secara langsung mahupun tidak langsung.

\section{Konsep Harta Sepencarian}

Harta sepencarian merupakan salah satu bentuk konsep kehartaan dalam perkahwinan yang mempunyai ciri-cirinya tersendiri. Harta sepencarian yang lahir daripada praktis amalan setempat dalam masyarakat Melayu Nusantara telah membuka dimensi baru dalam aspek pembahagian harta khususnya bagi pasangan suami dan isteri. Di samping itu juga, konsep harta sepencarian telah mula dibincangkan secara terperinci dalam kalangan sarjana akademik dalam menentukan apakah yang dimaksudkan dengan harta sepencarian.

\footnotetext{
${ }^{1}$ Jelani Harun (2008), “Kajian Naskhah Undang-Undang Adat Melayu di London,” Sari - Jurnal Antarabangsa Alam dan Tamadun Melayu, Jil. 26, h. 127-148

${ }^{2}$ Suwaid Tapah (1996), Konsep dan Amalan Harta Sepencarian Orang-Orang Islam di Malaysia, Tesis Doktor Falsafah, Jabatan Pengajian Islam, Fakulti Sastera dan Sosial, Universiti Malaya, h. 38-39.

${ }^{3}$ Mohd Norhusairi Mat Hussin (2014), Konsep Sumbangan Dalam Penentuan Pembahagian Harta Sepencarian di Mahkamah Syariah Malaysia: Perspektif Sosio-Perundangan, Tesis Doktor Falsafah, Jabatan Syariah dan Undang-Undang, Akademi Pengajian Islam, Universiti Malaya, h. 2.

4 Portal Rasmi Kerajaan Negeri Sembilan (t.t.), “Introduction of Adat Perpatih,” diakses 3 Februari 2020, http://www.ns.gov.my/en/kerajaan/info-negeri/adat-perpatih.
} 
Menurut Kamus Dewan, harta sepencarian telah didefinisikan sebagai harta yang diperoleh daripada usaha suami dan isteri. ${ }^{5}$ Pelbagai takrifan telah diberikan oleh para sarjana undang-undang dalam mendefinisikan harta sepencarian termasuklah para hakim Mahkamah yang mengendalikan kes-kes harta sepencarian, para ahli akademik dan sebagainya. MB Hooker umpamanya yang merupakan antara sarjana terawal Barat yang menulis tentang undang-undang keluarga di Malaysia telah mentakrifkan harta sepencarian sebagai harta yang diperoleh secara bersama oleh suami isteri dalam masa perkahwinan. ${ }^{6}$ Ter Haar seorang sarjana Barat pula mentakrifkan harta sepencarian sebagai harta yang diperoleh oleh suami dan isteri sebagai milik bersama dalam masa perkahwinan. ${ }^{7}$ Soekanto pula telah mendefinisikan harta sepencarian sebagai harta yang dibawa ke dalam perkahwinan kerana usaha bersama dari suami dan isteri. ${ }^{8}$

Para sarjana undang-undang tempatan juga telah memberikan definisi yang hampir sama kepada harta sepencarian, iaitu harta yang dikumpulkan sepanjang berlangsungnya tempoh perkahwinan. Sebagai contoh Mohd Akhir Hj. Yaakob menyatakan harta sepencarian sebagai harta yang diperolehi dalam masa perkahwinan seorang suami dengan isterinya. ${ }^{9}$ Menurut Suwaid Tapah pula harta sepencarian sebagai harta carian bersama dengan menegaskan bahawa elemen yang sangat penting dalam membincangkan harta sepencarian ini ialah usaha bersama suami isteri dalam memperoleh harta-harta yang dipertikaikan itu. ${ }^{10}$ Manakala Mimi Kamariah mentakrifkan harta sepencarian sebagai harta yang diperoleh hasil sumbangan bersama semasa tempoh perkahwinan. ${ }^{11}$ Seterusnya, Mat Saad Abdul Rahman pula memberikan definisi harta sepencarian sebagai harta yang diperoleh bersama oleh sepasang suami isteri setelah mereka berumah tangga. ${ }^{12}$ Oleh itu, berdasarkan kepada kepelbagaian definisi yang telah diberikan oleh para sarjana barat mahupun tempatan, penulis mendapati bahawa ianya memberikan satu konsep yang konsisten dan tidak bercanggah di antara satu sama lain. Maka, dapatlah disimpulkan bahawa harta sepencarian merupakan satu bentuk harta yang diperoleh dalam tempoh perkahwinan di antara suami dan isteri secara bersama sama ada secara langsung ataupun tidak langsung. Maka daripada konsep harta sepencarian tersebut dapat dikeluarkan ciri-ciri yang dikategorikan sebagai harta sepencarian adalah pertama harta yang diperoleh secara bersama suami dan isteri, keduanya harta yang diperoleh dalam tempoh perkahwinan dan ketiga terdapatnya elemen sumbangan sama ada langsung atau tidak langsung.

\section{Amalan Harta Sepencarian Mengikut Adat Melayu}

Secara keseluruhannya semua teori, spekulasi dan model baik dalam bidang bahasa, sejarah, arkaeologi, antropologi budaya, antropologi fizikal mahupun genetik mengenai asal-usul masyarakat peribumi di Nusantara sama ada secara sedar atau tidak adalah bergerak di atas landasan teori yang dianjurkan oleh Edward Sapir (1916). ${ }^{13}$ Menurut teori Sapir, dalam sesebuah wilayah besar yang mempunyai persamaan bahasa, artifak, biologi dan sebagainya, lokasi paling berencam dan paling padat adalah merupakan kemungkinan titik bermulanya unsur-unsur tersebut (bahasa, artifak, biologi dan sebagainya). ${ }^{14}$ Kata kunci dalam teori Sapir ialah 'keberencaman' dan 'kepadatan.' Sehubungan itu, tempat yang didapati paling berencam dan paling padat penggunaan bahasa, penemuan bahan arkaeologi, tumbuh-tumbuhan, haiwan, bahan-bahan antropologi dan unsur-unsur genetik merupakan tanah asal sesuatu bangsa atau kumpulan etnik. ${ }^{15}$ Paradigma atau landasan pemikiran inilah yang digunakan oleh para pengkaji yang mengemukakan teori, spekulasi dan model mengenai asal-usul nenek moyang peribumi Nusantara. ${ }^{16}$ Maka, daripada teori inilah bermulanya titik tolak kepada sejarah dan perkembangan masyarakat Melayu mengikut kajian sejarah dan antropologi. Oleh itu, amalan harta sepencarian adalah sebahagian daripada unsur-unsur yang menjadikan ia sebagai satu praktis asal sesuatu bangsa dan kumpulan dalam sesebuah masyarakat.

\footnotetext{
${ }^{5}$ Kamus Dewan, Ed. Ke-3 (2000), Kuala Lumpur: Dewan Bahasa dan Pustaka.

${ }^{6}$ M.B. Hooker (1976), Personal Laws of Malaysia, Oxford: Oxford University Press, h. 77.

${ }^{7}$ Pendapat beliau ini dirujuk oleh S.H SurojoWignjodipura (1971), Pengantar dan Asas-Asas Hukum Adat, Bandung: Penerbit Alumni, h. 203.

${ }^{8}$ Kamus Hukum Adat (1982), Bandung: Penerbit Alumni, h. 84.

${ }^{9}$ Mohd Akhir Hj. Yaacob (1984), "Harta Sepencarian,” Jurnal Hukum, Jil. 5, Bil. 1, h. 36.

${ }^{10}$ Suwaid bin Tapah (1996), Konsep dan Amalan Harta Sepencarian Orang-Orang Islam di Malaysia, h. 31.

${ }^{11}$ Mimi Kamariah Abdul Majid (1999), Family Law In Malaysia, Kuala Lumpur: Malayan Law Journal, h. 366.

12 Mat Saad Abdul Rahman (2007), Undang-Undang Keluarga Islam-Aturan Perkahwinan: Suatu Pendekatan Berdasarkan Amalan Semasa, Petaling Jaya: Intel Media Publication, h. 259.

${ }^{13}$ Edward Sapir (1916), Time Perspective in Aboriginal American Culture, Ottawa: Geological Survey Department of Mines.

${ }^{14}$ Sapir (1916), Time Perspective in Aboriginal American Culture.

${ }^{15}$ Sapir (1916), Time Perspective in Aboriginal American Culture.

${ }^{16}$ Sapir (1916), Time Perspective in Aboriginal American Culture.
} 
Sejarah juga telah menunjukkan amalan pembahagian harta sepencarian telah lama diamalkan dalam masyarakat Melayu. ${ }^{17}$ Perbincangan berkaitan dengan asal usul dan sumber amalan harta sepencarian turut menjadi polemik. Ini kerana harta sepencarian adalah sebahagian daripada hukum adat yang tidak bertulis pada awalnya. ${ }^{18}$ Bahkan amalan pembahagian harta sepencarian telahpun wujud sebelum kedatangan Islam ke Tanah Melayu, ${ }^{19}$ dan ianya menimbulkan kerumitan bagi mengenali sejarah dan asal usul amalan pembahagian sepencarian dalam masyarakat khususnya dalam menentukan sumber asal hukum adat tersebut. Para pengkaji adat telah merekodkan adat-adat yang dipakai dalam masyarakat Melayu termasuklah adat pembahagian harta sepencarian. ${ }^{20}$ Menerusi Adat Temenggung umpamanya mendefinisikan harta sepencarian sebagai harta yang diperoleh oleh keduadua suami dan isteri semasa perkahwinan. Seandainya perkahwinan itu telah mencapai usia tiga tahun dan pasangan tersebut telah mempunyai anak maka harta itu termasuklah apa-apa harta yang dipunyai oleh mana-mana pihak sebelum perkahwinan mereka. ${ }^{21}$

Mengikut prinsip asas, sekiranya terjadi suatu perceraian atau kematian mana-mana pihak maka kedua-dua pihak berhak mendapat bahagian di dalam harta sepencarian tersebut (dalam hal perceraian), atau pasangan yang masih hidup berhak mendapatkan harta sepencarian (dalam hal kematian). Kaedah pembahagiannya pula adalah seperti berikut: ${ }^{22}$

1. Jika si suami yang menceraikan tanpa ada sebarang kesilapan di pihak isteri, si suami mestilah memberi nafkah selama 3 bulan dan semua harta perlu dibahagikan. Harta yang merupakan senjata atau alat perang diserahkan kepada suami. Dia juga akan menanggung apa-apa hutang atau cukai. Manakala semua perkakasan rumah dan tembaga akan diserahkan kepada isteri. Beliau juga akan mendapat rumah yang mereka duduki serta tanah.

2. Jika si isteri yang memohon cerai, dia hanya akan diceraikan jika dia dapat membuktikan ada tiga kesilapan dipihak suami yang menyebabkan dia ingin bercerai dari suaminya. Setelah perceraian dia haruslah mengembalikan apa-apa harta boleh alih kepada suaminya.

\section{Amalan Pembahagian Harta Sepencarian Mengikut Adat Temenggung}

Pemakaian Undang-undang Adat Temenggung ini berbeza-beza dari satu negeri ke negeri yang lain, khususnya pada zaman sebelum reformasi undang-undang Keluarga Islam berlaku. ${ }^{23}$ Contohnya di Perak, ${ }^{24}$ apabila perceraian berlaku, seorang isteri yang telah menyumbangkan usahanya mengerjakan tanah milik pasangan tersebut, adalah berhak ke atas separuh daripada tanah yang diperolehi ketika perkahwinan. Manakala jika dia tidak memberikan apa-apa sumbangan, dia tetap akan mendapat 1/3 daripada harta sepencarian. Prinsip yang sama juga terpakai seandainya mana-mana pasangan meninggal dunia. Harta yang selebihnya akan diberikan kepada anak-anak atau ahli keluarga yang lain mengikut hukum pusaka. Untuk memudahkan kefahaman berkenaan amalan ini, dua contoh kes Mahkamah sebelum daripada kemerdekaan dikemukakan bagi menjelaskan pengaruh adat dalam pembahagian harta sepencarian dalam masyarakat Melayu.

Untuk membuktikan lagi amalan harta sepencarian dalam masyarakat Melayu telah lama berlaku, tidak lengkap sekiranya tidak melihat kes sebenar menerusi kes-kes yang telah dibicarakan dan diputuskan di Mahkamah Syariah. Beberapa contoh kes di Mahkamah Syariah boleh diteliti untuk menunjukkan bagaimana amalan ini telah bermula dan berkembang dengan baik dalam masyarakat Melayu. Bahkan, dalam kes-kes yang akan dihuraikan nanti, tiada kes yang menunjukkan perbezaan ketara dalam pengiktirafan yang diberikan oleh pihak kehakiman terhadap amalan ini. Ini membuktikan bahawa amalan pembahagian yang menjadi sebahagian sejarah dalam tamadun Melayu

\footnotetext{
${ }^{17}$ Tiada tarikh yang tepat bilakah amalan harta sepencarian ini diamalkan. Perkara sama telah dinyatakan oleh Datu Sulaiman, pemuka Adat Perpatih semasa temubual dengan Penulis pada 12 Julai 2012 di Pusat Dokumentasi dan Informasi Adat Perpatih, Padang Panjang, Kota Padang, Sumatera, Indonesia

${ }^{18}$ Suwaid Tapah (1996), Konsep dan Amalan Harta Sepencarian Orang-Orang Islam di Malaysia, h. 73.

${ }^{19}$ Suwaid Tapah (1996), Konsep dan Amalan Harta Sepencarian Orang-Orang Islam di Malaysia, h. 73.

${ }^{20}$ Malah, terdapat sesetengah sarjana Barat yang mengkaji adat masyarakat Melayu cuba untuk menghimpun kata perbilangan yang melambangkan pentadbiran dan amalan adat dalam masyarakat Melayu. Rujukan lanjut sila lihat A. Hale (1898), "Folklore and The Minangkabau Code in Negeri Sembilan," Journal of the Straits Branch of the Royal Asiatic Society, Jil. 31, h. 43-61.

${ }^{21}$ Othman Ishak (1982), Hubungan antara Undang-Undang Islam dengan Undang-Undang Adat, Kuala Lumpur: Dewan Bahasa dan Pustaka, h. 82.

${ }^{22}$ Othman Ishak (1982), Hubungan antara Undang-Undang Islam dengan Undang-Undang Adat, h. 82.

${ }^{23}$ Reformasi Undang-Undang Keluarga Islam berlaku dalam tahun 1980-an yang membawa kepada usaha penyeragaman Undang-Undang Keluarga Islam di Malaysia. Rujukan lanjut sila lihat Yusuf Abdul Azeez et al. (2016), "Codification of Islamic Family Law in Malaysia: The Contending Legal Intricacies," Journal Science International, Jil. 28, Bil. 2, h. 1753-1762.

${ }^{24}$ Suwaid Tapah (1996), Konsep dan Amalan Harta Sepencarian Orang-Orang Islam di Malaysia, h. 90
} 
telah diberikan oleh perlindungan undang-undang. Meskipun konsep pemilikan kehartaan orang Melayu adalah berbeza dengan sistem common law Inggeris, hakim-hakim Inggeris yang menghakimi kes-kes harta ini pada peringkat awal tetap mengiktiraf amalan harta sepencarian sesuai dengan sejarah amalan ini dalam masyarakat Melayu yang sekian lama dipraktiskan.

Contohnya, dalam kes Teh Rasim lwn Neman ${ }^{25}$ plaintif dan defendan, semasa tempoh perkahwinan mereka telah memperoleh sebidang tanah daripada kerajaan negeri dan telah menanamnya dengan pokok getah. Empat tahun kemudian, tanah itu telah dijual dan duit yang diperoleh daripada jualan itu telah digunakan oleh defendan (suami) untuk membeli tanah lain. Plaintif (isteri) telah mengusahakan sebahagian tanah yang dibeli oleh suaminya itu. Lapan belas tahun selepas mendirikan rumah tangga, defendan telah menceraikan plaintif. Plaintif kini menuntut satu pertiga nilai kesemua harta yang mereka miliki bersama. Mahkamah telah merujuk kes ini kepada Raja Chulan yang kemudiannya menasihatkan supaya kes ini diputuskan mengikut pendapat Majlis Diraja Sultan Perak. Berdasarkan nasihat Raja Chulan ini, Hakim Watson memutuskan bahawa plaintif (isteri) berhak mendapatkan satu pertiga bahagian harta daripada lima keping tanah yang didaftarkan di atas nama defendan. Kes ini telah diputuskan berasaskan prinsip undang-undang adat khususnya Adat Temenggung kerana walaupun telah dibuktikan bahawa plaintif diceraikan oleh defendan kerana melakukan zina, Plaintif tetap mendapat hak ke atas sepencarian. Dengan kata lain, perlakuan zina yang diharamkan oleh Syarak telah tidak menjejaskan tuntutan Plaintif terhadap harta sepencarian.

Sebenarnya konsep yang sama juga dapat dilihat dalam amalan pembahagian harta sepencarian di negeri-negeri yang lain. Di Selangor, dalam kes Haji Ramah lwn Alpha \& Ors, ${ }^{26}$ tuntutan isteri diasaskan pada konsep upah. Dalam kes ini, suami plaintif telah meninggal dunia, meninggalkan lima keping tanah sebagai harta pusaka. Selain menuntut bahagiannya berdasarkan faraid, plaintif juga telah menuntut sebahagian harta peninggalan suaminya itu berasaskan konsep upah kerana dia telah turut sama mengerjakan tanah itu. Pihak defendan yang terdiri daripada waris-waris si mati yang lain, telah menafikan dakwaan plaintif dan menyatakan bahawa plaintif tidak pernah mengerjakaan tanah tersebut. Reay JC telah memanggil seorang kadi untuk memberikan pendapat pakarnya. Kadi telah menyatakan bahawa jika seorang isteri membantu suaminya menebas, menanam atau mengerjakan kebun suaminya, dia berhak mendapat upah. Oleh itu, seorang balu boleh menuntut sebahagian tanah itu sebagai ganti kepada pampasan wang dan bahagian yang diberi itu boleh ditentukan mengikut budi bicara mahkamah. Konsep upah ini adalah undang-undang adat yang tidak bertentangan dengan hukum Islam dan diaplikasikan dalam menentukan hak seorang isteri dalam mendapatkan harta sepencariannya. Islam menerima pemakaian apa-apa adat selagi ianya tidak bertentangan dengan hukum Syarak.

\section{Amalan Harta Sepencarian Mengikut Adat Perpatih}

Selain daripada Adat Temenggung, Adat Perpatih juga turut memperuntukkan mengenai harta sepencarian. Namun begitu, ia menggunakan prisip yang agak berbeza. Menurut adat ini, harta sepencarian perlu dibahagikan mengikut prinsip berikut: 'Carian bahagi, Dapatan Tinggal, Pembawa Kembali, Suku Belah, Suarang Berageh'.27 Maksudnya adalah apa-apa harta yang diperolehi ketika berkahwin perlulah dibahagi di antara pasangan seandainya mereka bercerai. Jika mereka tiada anak dan suami mati maka harta itu akan menjadi milik isteri, prinsip yang sama juga terpakai jika isteri yang mati. Tetapi jika mereka mempunyai anak, maka pembahagian yang akan dilakukan ke atas harta tersebut perlulah dibincangkan terlebih dahulu dengan semua benefisiari.

Apabila kita meninjau amalan kehartaan di dalam adat perpatih, kita akan mendapati bahawa terdapat tiga konsep harta yang diamalkan iaitu harta sepencarian, harta pembawa dan harta dapatan. Ketigatiga jenis harta ini akan mempengaruhi pembahagian harta tersebut apabila berlakunya perceraian sama ada perceraian hidup mahupun perceraian mati. Dalam adat perpatih, harta pembawa ${ }^{28}$ ialah harta yang dimiliki oleh seseorang lelaki yang diperolehi sama ada ketika masih bujang atau harta yang diberikan oleh ibunya. Sekiranya berlaku perceraian antara suami dan isteri, maka harta tersebut

\footnotetext{
${ }^{25}$ Perak Supreme court No. 232, tahun 1919.

${ }^{26}$ Selangor Civil Suit No. 54, tahun 1924.

${ }^{27}$ Rujuk Othman Ishak: perkataan 'suarang berageh' juga dikenali sebagai 'mati laki tinggal ke bini, mati bini tinggl ke laki.'

${ }^{28}$ Nordin Selat (1975), Sistem Sosial Adat Perpatih, Kuala Lumpur: N.P. h. 117. Rujuk juga Suwaid Tapah (1996), Konsep dan Amalan Harta Sepencarian Orang-Orang Islam di Malaysia, h. 31.
} 
hendaklah dikembalikan semuanya kepada suku-sukunya (pihak lelaki sahaja), lebih-lebih lagi jika si suami meninggal dunia. Ini bermakna si isteri tidak berhak untuk mendapatkan harta tersebut meskipun harta tersebut menjadi milik suaminya ketika si suami masih hidup. ${ }^{29}$ Harta Dapatan ${ }^{30}$ pula ialah harta yang dimiliki oleh seseorang wanita sebelum daripada perkahwinannya dengan si suami. Harta ini diperolehinya sama ada secara pemberian ataupun melalui hasil usahanya sendiri sebelum daripada perkahwinan tersebut. Si suami hanya boleh untuk mengusahakan harta tersebut tetapi bukan memiliki harta tersebut kerana hak milik harta tersebut masih menjadi milik si isteri. Dalam kes harta seumpama ini, jika berlaku perceraian terhadap pasangan tersebut, maka si suami tidak berhak untuk mendapatkan harta tersebut. Sebaliknya harta tersebut akan diberikan kepada anak perempuan daripada pasangan tersebut. Sekiranya pasangan tersebut tidak mempunyai zuriat, maka harta tersebut hendaklah diserahkan kepada ahli keluarga atau suku perempuan tersebut.

Sebaliknya harta sepencarian pula merupakan harta yang diperolehi secara bersama oleh pasangan tersebut sepanjang berlangsungnya tempoh perkahwinan mereka. Oleh kerana harta ini diperolehi dari usaha bersama di antara suami dan isteri maka harta ini perlu dibahagi sama rata jika berlaku perceraian di antara kedua-dua pihak. Jika perceraian berlaku disebabkan kematian pula, maka pihak yang masih hidup akan membahagikan harta tersebut dengan anak-anak. Di dalam adat perpatih, prinsip pembahagiannya dapat diketahui melalui ungkapan:

Pembawa kembali,

Dapatan tinggal,

Carian bahagi,

Mati laki tinggal ke bini,

Mati bini tinggal ke laki.

Dalam adat perpatih, persoalan pembahagian harta perkahwinan selepas berlakunya perceraian kurang menimbulkan pertikaian. Ini kerana pembahagian jenis harta yang diamalkan dalam masyarakat perpatih itu sendiri telah ditentukan pembahagiannya sekiranya berlaku perceraian kepada sesebuah pasangan khususnya yang melibatkan harta pembawa dan harta dapatan. Sungguhpun begitu, pembahagian harta sepencarian masih lagi agak rumit berbanding dengan harta dapatan dan harta pembawa dalam konteks perbincangan harta perkahwinan dalam adat perpatih. Ini kerana di dalam harta yang dikatakan harta pembawa, mungkin wujudnya juga elemen harta sepencarian. Tetapi adalah tidak mungkin dalam harta yang dikatakan harta sepencarian itu, wujudnya harta pesaka atau harta pembawa. ${ }^{31}$

Menurut Adat Perpatih, harta sepencarian tidak termasuk apa-apa harta yang diperoleh oleh suami sebelum perkahwinan dan dibawa masuk ke dalam perkahwinan. Harta tersebut akan dipulangkan kepadanya semula jika bercerai dan jika mati kembali kepada sukunya. Prinsip yang sama juga diaplikasikan kepada isteri. Pembahagiannya akan dilakukan setelah semua hutang dilangsaikan. Jumlahnya adalah sama rata di antara suami dan isteri walaupun mereka mempunyai anak ataupun isteri itu diceraikan kerana berzina. Pengecualian kepada prinsip pembahagian ini adalah jika perceraian itu adalah menerusi cerai taklik. Dalam hal ini maka si isteri akan mendapatkan keseluruhan harta sepencarian. Bersama-sama dengan undang-undang adat, pengaruh undang-undang Islam tidak dapat dinafikan dalam membicarakan berkaitan harta sepencarian di Tanah Melayu pada ketika itu.

\section{Amalan Pembahagian Harta Sepencarian Mengikut Undang-Undang Islam}

Islam mengiktiraf bahawa adat, baik secara khusus ataupun umum adalah menjadi salah satu sumber Hukum Syarak ${ }^{32}$ dan sesuatu adat itu boleh diterima apabila sudah mejadi kelaziman atau kebiasaan sedemikian. Ini menunjukkan bahawa Islam meraikan adat kebiasaan yang diamalkan oleh umatnya di kawasan-kawasan tertentu yang tidak bercanggah dengan hukum Islam. Sejarah perundangan Islam sendiri telah menunjukkan apabila Rasulullah SAW berhadapan dengan permasalahan adat ('urf),

\footnotetext{
${ }^{29}$ Ahmad Damiri Yahaya (1990), Kes-Kes Harta Sepencarian Mengikut Adat Perpateh dan Hukum Syara' di Negeri Sembilan: Satu Ulasan, Petaling Jaya: Universiti islam Antarabangsa, h. 139.

${ }^{30}$ Ahmad Damiri (1990), Kes-Kes Harta Sepencarian Mengikut Adat Perpateh, h. 140.

${ }^{31}$ Suwaid Tapah (1996), Konsep dan Amalan Harta Sepencarian Orang-Orang Islam di Malaysia, h. 31; Ahmad Damiri (1990), Kes-Kes Harta Sepencarian Mengikut Adat Perpateh, h. 140.

${ }^{32}$ Lihat dalam Perkara 36, Majalah Ahkam al-'Adliyyah (1968), Cet. Ke-5, Tahun 1968, Beirut: Matba'ah Sha'ari'.

${ }^{33}$ Mohd Ridzuan Awang (1987), Konsep Undang-Undang Tanah Islam: Pendekatan Perbandingan, Kuala Lumpur: al-Rahmaniah, h. 133.
} 
baginda mengambil sikap yang berbeza di antara satu adat dengan adat yang lain sama ada menerima, menolak atau menerima dengan pindaan sesuatu adat untuk menjadi hukum. Apabila sesuatu adat atau 'uruf itu diakui kebaikannya dan mendapat pengiktirafan undang-undang, kedudukannya bukan lagi sebagai adat, tetapi bertukar menjadi satu peraturan atau perundangan yang mesti dikuatkuasakan. ${ }^{34}$ Keadaan ini adalah sangat bertepatan dengan prinsip Syariah Islam yang memelihara adat dan 'uruf manusia dengan syarat tidak berlaku kerosakan dan tidak hilang kepentingan (maslahah) kehidupan. ${ }^{35}$

Secara etimologinya, perkataaan 'urf berasal daripada perkataan Arab iaitu 'arafa yang bererti mengetahui. Al-Jurjani dalam kamus istilahnya al-Ta'rifat, menjelaskan istilah 'urf sebagai perbuatan atau kepercayaan dalam mana orang berpegang teguh dengan persetujuan kekuatan mental dan tabiat semula jadi mereka juga mahu menerimanya sebagai benar. ${ }^{36}$ Al-Zuhayli ${ }^{37}$ mendefinisikan 'urf sebagai kebiasaan yang diterima umum dan berakar umbi dalam masyrakat. Manakala Abu Zuhrah ${ }^{38}$ menghuraikan 'urf sebagai perkara yang menjadi kebiasaan orang ramai dalam transaksi (mu'amalah) dan mereka bersikap konsisten dalam urusan mereka. Tegasnya 'urf ini merupakan adat atau amalan kebiasaan yang diterima dan diamalkan oleh penduduk setempat tanpa menimbulkan bantahan dan kekeliruan dalam anggota masyarakat. Ianya dikuatkan lagi dengan 'urf atau adat tersebut tidak bercanggah dengan ajaran Islam yang menjadi pegangan masyarakat khususnya masyarakat Melayu di Malaysia dan di Nusantara amnya. Sehubungan dengan itu, 'urf dan adat mempunyai signifikan yang tersendiri sebagai sumber dan instrumen hukum dalam sesebuah masyarakat. ${ }^{39}$ Berdasarkan kenyataan tersebut, 'urf perlu diambil kira sebagai nilai tempatan yang menjadi asas kepada pembentukan hukum Islam. ${ }^{40}$

Seperti mana yang telah diketahui bahawa harta sepencarian ini hanya wujud di dalam budaya masyarakat Melayu ataupun rumpun Melayu di kepulauan Nusantara ini. Ini kerana konsep pemilikan harta bagi wanita berkahwin adalah berbeza dengan prinsip common law Inggeris ${ }^{41}$ yang menyatakan bahawa apabila seseorang perempuan berkahwin, maka hartanya termasuk dengan harta suaminya. ${ }^{42}$ Akan tetapi prinsip ini telah tidak dikenakan ke atas orang-orang Islam dan ini telah diputuskan dalam beberapa kes yang awal, antaranya ialah Hawah v Daud. Dalam kes ini pihak Plaintif merupakan bekas isteri kepada pihak Defendan dan telah mengemukakan tuntutan harta-harta yang diperolehi sepanjang tempoh perkahwinan Plaintif dan Defendan. Plaintif telah berjaya membuktikan kepada Mahkamah bahawa wujud sumbangan yang disumbangkan oleh Plaintif dalam memperolehi hartaharta dalam perkahwinan tersebut. Mahkamah akhirnya telah memutuskan yang Plaintif berhak untuk mendapatkan sebahagian daripada harta sepencarian yang diperolehi dalam tempoh perkahwinan Plaintif dan Defendan. Sungguhpun kes ini dibicarakan di hadapan hakim Inggeris, prinsip dalam common law Inggeris iaitu seorang isteri tidak berhak untuk mendapat harta perkahwinan tidak diaplikasikan. Mahkamah sebaliknya telah menerima prinsip pemilikan kehartaan oleh wanita dalam amalan adat dan hukum Islam yang berkuat kuasa di tanah Melayu pada waktu itu. Wanita dalam Islam masih boleh terus memiliki serta menguruskan harta yang diperolehinya sebelum daripada perkahwin tanpa boleh dihalang oleh para suami, malah para wanita di dalam Islam boleh serta berkeupayaan untuk berkontrak serta bermuamalah di dalam undang-undang Islam. ${ }^{43}$

Berasaskan prinsip relativisme budaya, masyarakat Melayu khususnya juga mempunyai pola hubungan gender yang berbeza dengan dari kawasan keIslaman yang lain. Masyarakat Melayu bersifat mesra wanita yang mana tiada adat dan tradisi yang diskriminatif dalam amalan seharian. ${ }^{44}$ Malah, dalam masyarakat Melayu, sejak dahulu lagi tidak begitu membezakan tentang kelahiran anak

\footnotetext{
${ }^{34}$ Zaini Nasuhah (2002), Perceraian: Hak Islam, Kuala Lumpur: Lohprint Sdn. Bhd., h. 78.

${ }^{35}$ Muhammad Sa'id Ramadan al-Buti (1966), Dawabit al-Maslahah fi al-Shari'ah al-Islamiyyah, Damsyik: al-Maktabah al-Umawiyyah, h. 81 .

36 'Ali Muhammad al-Jurjani (1405H), al-Ta'rifat, Beirut: Dar al-Kitab al-'Arabi, h. 193

${ }^{37}$ Wahbah al-Zuhayli (1998), Usul Fiqh al-Islami, cet. 2, Damsyik: Dar al-Fikr, h. 830.

${ }^{38}$ Muhammad Abu Zuhrah (1985), Usul al-Figh, Kaherah: Dar al-Fikr al-‘Arabi, h. 216.

${ }^{39}$ Mohd Norhusairi Mat Hussin dan Mohd Anuar Ramli (2013), "Pengambilkiraan 'Urf dan Adat Masyarakat Setempat: Analisis Terhadap Amalan Harta Sepencarian,” dalam Mohd Yacob@Zulkifli, et al. (ed.), Dimensi Penyelidikan Dalam Bidang Pengajian Islam, Kuala Lumpur: Akademi Pengajian Islam, Universiti Malaya, h. 321.

${ }^{40}$ Mohd Norhusairi dan Mohd Anuar (2013), "Pengambilkiraan 'Urf dan Adat Masyarakat Setempat,” h. 321.

${ }^{41}$ Rujukan lanjut untuk melihat kedudukan wanita dalam masyarakat Melayu dan masyarakat lain, sila lihat Arba’iyah Mohd Noor (2020),

"The Transition of Malay Women Role and Contribution in Early $20^{\text {th }}$ Century," Journal of Tamaddun, Jil. 15, Bil. 1, h. 67-84

${ }^{42}$ Mohd Akhir (1984), "Harta Sepencarian," h. 36.

${ }^{43}$ Rujukan lanjut, sila lihat dalam Ahmad Hidayat Buang (2001), "Keupayaan Wanita untuk Berkontrak Di Dalam Undang-Undang Islam," dalam Raihanah Abdullah (ed.), Wanita dan Perundangan Islam, Selangor: Ilmiah Publishers, h. 16-37.

${ }^{44}$ Mohd Norhusairi dan Mohd Anuar (2013), "Pengambilkiraan 'Urf dan Adat Masyarakat Setempat,” h. 323.
} 
lelaki mahupun anak perempuan. ${ }^{45}$ Kedua-dua anak tersebut diterima dan diasuh dengan sebaiknya tanpa wujudnya perbezaan layanan terhadap jantina anak yang dilahirkan. Kelahiran mana-mana jantina dianggap sebagai anugerah Allah SWT. ${ }^{46}$ Kebiasaannya anak lelaki dan perempuan melalui proses sosialisasi yang berbeza sesuai dengan peranan masing-masing. ${ }^{47}$ Oleh kerana isteri-isteri yang beragama Islam dalam masyarakat Melayu diberikan hak yang setara dengan kaum lelaki dari segi pekerjaan, maka para wanita Islam di kawasan Nusantara ini yang banyak melibatkan di lapangan sosial dan pekerjaan untuk membantu para suami. Atas tugas dan peranan mereka di luar rumah bagi membantu suami meningkatkan ekonomi dan untuk mendapatkan harta inilah, maka adat Melayu telah memperuntukkan untuk mereka supaya mendapat bahagian daripada Harta Sepencarian. ${ }^{48}$

Adat ini telah diperkuatkan lagi dengan adanya pengisytiharan berkaitan dengan pembahagian harta selepas perceraian daripada Majlis Kerajaan Negeri Perak bertarikh 18 Januari 1907. Majlis telah mengisytiharkan dan mencatatkan: "Bahawa adat orang-orang Melayu di Perak dalam hal pembahagian harta sesudah perceraian, di mana harta itu diperolehi oleh pihak-pihak atau oleh salah seorang daripada mereka selama perkahwinan adalah dua bahagian bagi lelaki dan satu bahagian bagi perempuan dan pemberian-pemberian antara mereka tidak dapat dibatalkan baik selama perkahwinan mahupun selepas perceraian". 49 Perisytiharan ini menunjukkan bahawa terdapatnya hukum adat yang diguna pakai di dalam pembahagian harta yang diperolehi semasa tempoh perkahwinan sesuatu pasangan yang bercerai.

Bahkan pembahagian 1/3 yang ditetapkan oleh Majlis Kerajaan Negeri Perak tersebut mungkin terjadi kerana wujudnya tolak ansur adat dan prinsip umum harta pusaka Islam yang mana bahagian lelaki adalah dua bahagian seorang perempuan. ${ }^{50}$ Boleh juga dinyatakan bahawa kepentingan bagi lelaki memperolehi bahagian yang lebih besar sebagaimana selari atau ditiru dengan adat tempatan, tidaklah boleh ditafsirkan sebagai penyataan keutamaan bagi orang lelaki. ${ }^{51} \mathrm{Hal}$ ini kerana umum mengetahui bahawa orang lelaki mempunyai tanggung jawab yang lebih besar terhadap keluarga khususnya kepada anak-anak meskipun peceraian telah berlaku antara sesuatu pasangan tersebut. Tanggungjawab orang lelaki sama ada dalam Islam mahupun adat setempat telah menetapkan bahawa mereka wajib untuk menanggung nafkah anak sehinggalah anak-anak tersebut mencapai usia yang boleh berdikari ataupun telah melangsungkan perkahwinan bagi anak perempuan. Tanggungjawab ini merupakan tanggungjawab yang berterusan meskipun berlakunya perceraian dalam rumah tangga pasangan tersebut. Ini bermakna tanggungjawab untuk menafkahi anak-anak tidak terputus meskipun hubungan perkahwinan antara seorang lelaki dan wanita itu telah berakhir.

Konsep harta sepencarian yang didasari daripada hukum adat ini ditegaskan semula oleh Mahkamah dalam kes Roberts lwn Umi Kalthom ${ }^{52}$ di mana Raja Azlan Shah H telah menyatakan bahawa:

Satu prinsip yang boleh didapati daripada kes-kes tersebut yang telah memutuskan bahawa harta sepencarian ialah adat Melayu dan dipakai hanya dalam kes di mana suami/isteri yang dicerai menuntut dari isteri/suaminya dalam masa hidupnya; kaedah undang-undang itu adalah undang-undang tempatan yang mana Mahkamah hendaklah memberi pengiktirafan kehakiman dan menjadi tugas kepada Mahkamah mengisytiharkannya, lihat Ramah lwn Laton (1927) FMSLR 116. Memandang kepada autoriti yang begitu kuat, saya berpendapat bahawa telah dibuktikan dengan jelas apabila harta diperolehi selepas sesuatu perkahwinan dari sumber mereka bersama atau usaha bersama mereka, suatu anggapan ditimbulkan bahawa harta tersebut adalah harta sepencarian...

\footnotetext{
${ }^{45}$ Mohd Norhusairi dan Mohd Anuar (2013), "Pengambilkiraan 'Urf dan Adat Masyarakat Setempat,” h. 323.

${ }^{46}$ Raja Rohana Raja Mamat (1991), Peranan dan Status Wanita Melayu di Malaysia: Daripada Perspektif Sosial dan Undang-Undang,

Kuala Lumpur: Dewan Bahasa dan Pustaka, h. 22.

${ }^{47}$ Mohd Anuar Ramli (2005), “Konsep Masyarakat Melayu Mengenai Hubungan Gender,” Jurnal Yadim, Jil. 6, h. $141-154$.

${ }^{48}$ Mohd Akhir (1984), "Harta Sepencarian," h. 36.

${ }^{49}$ E. N. Taylor (1937), “Malay Family Law," Journal of the Royal Asiatic Society Malayan Branch, Jil. 1, h. 41.

${ }^{50}$ Othman Ishak (1997), Hubungan antara Undang-Undang Islam dengan Undang-Undang Adat, Cet. Ke-2, Kuala Lumpur: Dewan Bahasa

dan Pustaka, h. 96.

${ }_{51}$ Othman Ishak (1997), Hubungan antara Undang-Undang Islam dengan Undang-Undang Adat, h. 96.

52 [1966] 1 MLJ 163.
} 
Sejarah dan Perkembangan Amalan Pembahagian Harta Sepencarian dalam Masyarakat Islam di Malaysia Kes ini kemudiannya ditegaskan lagi dalam kes Boto' bte Taha lwn Jaafar. ${ }^{53}$ Dalam penghakimannya, Tun Salleh Abas yang merupakan Hakim Besar Malaya pada waktu itu telah menyatakan bahawa: "Harta Sepencarian tidak begitu bergantung kepada fiqh Islam, bahkan bergantung kepada adat yang diikuti oleh orang Melayu. Ia diamalkan di Indonesia dan harta-harta yang termasuk di bawahnya adalah dirujuk sebagai sharikah (Laton lwn Ramah)..."

Kes-kes harta sepencarian tersebut dibicarakan di Mahkamah Sivil memandangkan belum ada pengasingan kuasa sebagaimana selepas pindaan perkara 121 1(A) ${ }^{54}$ Perlembagaan Persekutuan sebagai mana yang ada pada hari ini. ${ }^{55}$ Semua kes dan fakta yang dinyatakan tersebut telah menunjukkan konsep harta sepencarian yang berasal daripada adat orang Melayu yang tidak bercanggah dengan hukum Syarak serta telah diiktiraf oleh undang-undang Islam yang wujud di Malaysia pada hari ini.

Apa yang jelas adat ini merupakan adat yang langsung tidak bercanggah dengan hukum Islam, bahkan memberi keadilan dan jaminan pemilikan harta perkahwinan kepada kedua-dua belah pihak sama ada suami ataupun isteri. Adat melayu yang telah diamalkan sekian lama telah mengangkat martabat kaum wanita khususnya yang dinafikan hak memiliki harta di bawah common law Inggeris serta adat masyarakat arab Jahiliah yang mendominasi sistem sosial masyarakat di awal kedatangan Islam dahulu. Bahkan, hak-hak yang tidak diperolehi sebelum kedatangan Islam, telah dapat dinikmati oleh kaum wanita seperti hak terhadap harta pusaka, hak memiliki mahar, hak talaq dan sebagainya. ${ }^{56}$ Konsep ini jelas selari dengan ajaran Islam yang tidak pernah membeza-bezakan manusia dalam pemilikan harta, hak bertasarruf, serta melihat manusia pada taraf yang sama tanpa mengira jantina, keturunan dan warna kulit. Islam sememangnya menolak sebarang diskrimanasi gender kerana Allah SWT mencipta manusia sesuai dengan peranan masing-masing sama ada lelaki mahupun wanita. Keadaan ini juga sesuai dengan senario kaum wanita Malaysia yang mempunyai hak yang sama dengan kaum lelaki dalam memiliki dan menguruskan harta-harta mereka. ${ }^{57}$ Keadaan ini tetap tidak berubah meskipun setelah mereka mendirikan rumah tangga.

Sungguhpun begitu, sudah terdapat pandangan dan ijtihad daripada ulama' yang berasal daripada Kepulauan Melayu berkaitan dengan konsep harta sepencarian ini. Malah timbulnya istilah samasama sepencari menjadi asas penting dalam konsep harta sepencarian yang kita kenali pada hari ini sebagaimana yang telah digambarkan oleh sebahagian ulama' fiqh alam melayu yang mana mereka telahpun menyelesaikan persoalan yang timbul di dalam ijtihad mereka. ${ }^{58}$ Oleh yang demikian, persoalan penerimaan hukum Islam terhadap konsep harta sepencarian ini tidak lagi perlu dipertikaikan memandangkan ianya mempunyai asas dan dasar yang kuat dalam hukum Islam. Selain daripada tidak bercanggah dengan hukum Islam, ianya juga ternyata mendatangkan kebaikan serta menjaga hak dan maslahah bagi kaum wanita khususnya apabila sesuatu perceraian berlaku di dalam sesebuah rumah tangga. Harta sepencarian menjadikan hak wanita muslim lebih terjaga meskipun mereka bukanlah penyumbang utama di dalam pemerolehan sesuatu aset di dalam tempoh perkahwinan. Keadaan ini adalah sesuai dan sejajar dengan firman Allah SWT:

Dan janganlah kamu terlalu mengharapkan (ingin mendapat) limpah kurnia yang Allah telah berikan kepada sebahagian dari kamu (untuk menjadikan mereka) melebihi sebahagian Yang lain (tentang harta benda, ilmu pengetahuan atau pangkat kebesaran). (kerana telah tetap) orang-orang lelaki ada bahagian dari apa Yang mereka usahakan, dan orang-orang perempuan pula ada bahagian dari apa Yang mereka usahakan; (maka berusahalah kamu) dan pohonkanlah kepada Allah akan limpah kurniaNya. Sesungguhnya Allah sentiasa mengetahui akan tiap-tiap sesuatu. ${ }^{59}$

\footnotetext{
53 [1985] 2 MLJ 98

${ }_{54}$ Peruntukan ini berkuat kuasa pada 10 Jun 1988 mengikut (Akta 704).

55 Sebelum daripada pindaan ini dibuat, pihak-pihak yang bertikai bebas untuk memilih mana-mana Mahkamah yang dirasakan boleh member banyak faedah kepada pihak-pihak tersebut. Ini kerana sebelum daripada pindaan, tiada peruntukan yang nyata tentang bidang kuasa Mahkamah Shariah untuk mengarahkan perlaksanaan tertentu pembahagian separuh bahagian harta kepada pihak-pihak yang bertikai. Sila rujuk Suwaid Tapah (1996), "Elemen Sumbangan Dalam Amalan Pembahagian Harta Sepencarian di Malaysia," Monograf Shariah, h. 66-67.

${ }^{56}$ Nur Saadah Hamisan@Khair, "Ulasan Buku: Nasaruddin Umar (2003), Teologi Jender: Antara Mitos Dan Teks Kitab Suci,” Journal of Al-Tamaddun, Jil. 14, Bil. 1, h. 118.

${ }^{57}$ Zaleha Kamaruddin (2000), "Islamic Family Law In Malaysia: An Overview," dalam Zaleha Kamaruddin (ed.), Islamic Family Law Issues, Gombak: IIUM Press, h. 24.

${ }_{58}^{58}$ Lihat Shaykh Ahmad bin Muhammad Zayn Mustafa Al-Fatani (1377H), al-Fatawa al-Fataniyyah, Siam: Cetakan Pattani Press, h. 104.

${ }^{59}$ an-Nisa', 4:32
} 
...dan isteri-isteri itu mempunyai hak yang sama seperti kewajipan Yang ditanggung oleh mereka (terhadap suami) Dengan cara yang sepatutnya (dan tidak dilarang oleh syarak); Dalam pada itu orang-orang lelaki (suami-suami itu) mempunyai satu darjat kelebihan atas orang-orang perempuan (isterinya). dan (ingatlah), Allah Maha Kuasa, lagi Maha Bijaksana. $^{60}$

\section{Sumbangan Isteri Dalam Harta Sepencarian}

Sejak Islam sampai ke Nusantara dan menjadi agama anutan majoriti penduduknya khususnya orang Melayu, para sejarawan sering membincangkan banyak isu berkaitan dengan Islam dan pengaruhnya ${ }^{61}$ terhadap struktur budaya dan amalan dalam masyarakat. Sebenarnya dalam masyarakat Melayu, perbezaan gender tidak mendatangkan permasalahan yang besar kerana perbezaan ini dilihat dalam perspektif yang positif. Bahkan pembahagian hak antara lelaki dan wanita telah sangat jelas khususnya pada undang-undang adat perpatih yang diamalkan di sebahagian kawasan di Negeri Sembilan dan Melaka. Pada awalnya masyarakat Melayu tradisonal telah menentukan bahawa tempat wanita adalah dalam lingkungan keluarga dan rumah tangga di mana mereka dijangka memegang status tradisional sebagai isteri, anak perempuan, adik atau kakak. ${ }^{62}$ Apabila dewasa dan berkahwin mereka menduduki status sebagai isteri dan ibu. ${ }^{63}$ Pandangan dan kedudukan kaum wanita Melayu ini kekal dalam struktur sosial masyarakat Melayu dalam jangka waktu yang lama. Ini kerana masyarakat Melayu melihat kaum wanita bukanlah satu golongan yang perlu keluar untuk mencari rezeki bagi menyara kehidupan keluarga. Tanggungjawab tersebut merupakan tanggungjawab yang seharusnya dipikul oleh orang lelaki. Pola-pola sosiolisasi dalam kalangan orang-orang Melayu telah sedikit sebanyak menyediakan anak-anak gadis untuk memainkan peranan mereka sebagai isteri dan ibu. ${ }^{64}$ Anak-anak gadis terikat dengan aktiviti-aktiviti di dalam rumah. Mereka diajar untuk membantu ibu mereka membuat kerja-kerja domestik seperti memasak, membasuh dan menjaga adik-adik yang masih kecil. ${ }^{65}$ Ini adalah bertujuan untuk melengkapkan diri mereka dengan tugas-tugas sebagai seorang isteri dan seorang ibu apabila berumah tangga kelak. Pembahagian ini tidaklah merendahkan martabat seorang perempuan, tetapi menempati golongan perempuan dalam posisi yang sesuai pada ketika itu. Ini terbukti dengan tiadanya konflik dalam soal pembahagian posisi masing-masing dalam rumah tangga ini.

Kaum lelaki pula dianggap sebagai ketua keluarga, pencari sumber rezeki yang utama serta menjadi tonggak dalam sesebuah keluarga dalam masyarakat Melayu. Pembahagian tugas dan tanggungjawab antara kaum lelaki dan kaum wanita adalah sangat jelas. Kaum wanita lebih tertumpu kepada tugastugas domestik seperti memasak, menguruskan rumah tangga, membasuh pakaian, menjaga serta mengasuh anak, ${ }^{66}$ sementara kaum lelaki pula sangat tertumpu kepada kerja-kerja di luar rumah bagi mencari rezeki untuk keluarga. Malah, seorang perempuan Melayu tidak akan dipandang tinggi jika didapati tidak pandai menguruskan rumah tangga apabila usianya menginjak dewasa ${ }^{67}$ Oleh yang demikian, struktur sosial masyarakat Melayu sememangnya telah menunjukkan bahawa kaum wanitanya merupakan "pengurus" kepada tugas-tugas domestik yang melibatkan urusan rumah tangga serta penjagaan anak-anak sementara kaum lelaki pula merupakan pencari rezeki di luar rumah. Struktur ini kemudiannya telah mengalami perubahan kerana faktor-faktor yang berlaku seperti perubahan sosial masyarakat secara umum, desakan ekonomi, pencapaian dalam pendidikan oleh kaum wanita dan sebagainya.

Sungguhpun banyak terlibat dalam urusan domestik pada awalnya, kaum wanita Melayu tetap juga terlibat dalam aktiviti ekonomi tradisional bersama kaum lelaki. Penglibatan ini adalah kesan daripada desakan ekonomi serta sifat ingin membantu yang telah diberikan secara sukarela oleh seorang isteri kepada suaminya. Penglibatan ini disokong pula dengan tidak wujudnya halangan atau sekatan daripada kaum lelaki khususnya para suami untuk tidak membenarkan para isteri membantu mereka

\footnotetext{
60 al-Baqarah, 2: 228

${ }^{61}$ Faisal@ Ahmad Faisal bin Abdul Hamid (2019), "Sistem Tulisan Jawi Dalam Manuskrip Hikayat Raja Handak MS172 (1832M)," Journal of Al-Tamaddun, Jil. 14, Bil. 1, h. 129.

${ }^{62}$ Fatimah Abdullah (1985), “Wanita Dan Pekerjaan: Satu Analisis Konflik Peranan,” Jurnal Akademika, Jil. 27, h. 83.

${ }^{63}$ Fatimah (1985), "Wanita Dan Pekerjaan," h. 83.

${ }^{64}$ M. G. Swift (1965), Malay Peasant Society in Jelebu, New York: Athlone Press, h. 107.

${ }^{65}$ P. J. Wilson (1967), A Malay Village and Malaysia, New Haven: Harf Press, h. 130.

${ }^{66}$ M. G. Swift (1963), "Man and Women in Malay Society," dalam B. E. Ward (ed.), Women in the New Asia, UNESCO, h. 277.

${ }^{67}$ Abu Hassan Othman (1972), "Struktur famili dan tingkah laku kekeluargaan di Selemak: Satu kajian kes," Jurnal Akademika, Jil.1, h. 1541
} 
dalam aktiviti ekonomi atau pertanian yang dijalankan. Usaha dan pertolongan yang dilakukan oleh para isteri ini telah dianggap sebagai perkongsian dalam mengukuhkan ekonomi keluarga. Sunggupun begitu, para isteri yang menjalankan kegiatan ekonomi ini tidaklah diharapkan untuk mencari wang bagi membeli barang-barang keperluan keluarga. ${ }^{68}$ Ini kerana kegiatan yang dijalankan tersebut dianggap sebagai satu bentuk bantuan dan perkongsian untuk menambah pendapatan para suami. Namun keadaan ini tidaklah menafikan wujudnya kegiatan ekonomi yang telah pun dijalankan oleh kaum wanita Melayu sejak dahulu lagi. Kaum wanita Melayu secara tradisionalnya telah terlibat dalam pekerjaan bersama kaum lelaki dalam bidang pertanian dan di pasar-pasar semenjak sebelum kedatangan penjajah. ${ }^{69}$ Begitu juga selepas kedatangan penjajah. ${ }^{70}$ Selain itu, kaum wanita juga bersama membantu suami dalam aktiviti pertanian khususnya sawah padi. ${ }^{71}$ Kaum wanita juga terlibat dalam aktiviti menoreh getah dan penternakan ayam. ${ }^{72}$ Pendek kata, kebanyakan kaum wanita di Malaysia mempunyai peranan berganda iaitu dalam urusan rumahtangga dan sektor ekonomi untuk menjana pendapatan keluarga.

Oleh yang demikian di Malaysia, kaum wanita memainkan peranan berganda sama ada dalam sektor domestik (rumah tangga) atau bukan domestik (luar rumah tangga). Mereka merupakan golongan yang berkerjaya untuk meringankan bebanan rumah tangga. Para isteri perlu turun ke medan kerja untuk membantu para suami. Menurut Firth, walaupun orang Melayu beragama Islam, tetapi kaum wanita tidak dihalang daripada memainkan peranan yang amat penting dalam sektor ekonomi. ${ }^{73}$ Bahkan, apabila sejarah perkembangan pekerjaan kaum wanita, maka kita akan mendapati bahawa kaum wanita di Malaysia dan Asia Tenggara telah pun terlibat dalam sektor ekonomi yang membantu untuk menjana pendapatan keluarga. Pada peringkat permulaan, kaum wanita terlibat dalam sektor pertanian sara diri. $^{74}$ Mereka turun mengerjakan sawah dan tanah untuk mendapatkan hasil bagi menampung kehidupan keluarga khususnya daripada aspek makanan.

Apabila terdapat lebihan daripada sektor pertanian, lebihan tersebut mula dipasarkan dan aktiviti pertukaran ini berlaku di pasar. ${ }^{75}$ Situasi ini membawa kepada penglibatan kaum wanita Melayu yang lebih aktif meliputi bidang pertanian dan perniagaan. Hasil pertanian yang diusahakan oleh para wanita tadi telah membawa kaum wanita untuk menyumbang dalam satu sektor yang lain dan seterusnya menyumbang kepada ekonomi keluarga dan rumah tangga. Fenomena penguasaan wanita dalam perniagaan pasar masih dapat dilihat sampai ke hari ini terutamanya di negeri Kelantan, Terengganu, Thailand dan Indonesia. ${ }^{76}$ Keadaan ini telah membuktikan bahawa penyertaan wanita di kawasan Nusantara ini ke lapangan sosial dan pekerjaan telah lama berlaku tanpa wujudnya sebarang halangan mahupun gangguan daripada adat mahupun agama yang dianuti oleh mereka. Masyarakat menerima keadaan ini sebagai satu norma yang mesti dihormati serta memberikan peluang yang baik kepada kaum wanita untuk meneruskan kegiatan luar rumah yang bermanfaat untuk ekonomi keluarga.

Walaupun begitu, corak dan penglibatan kaum wanita telah berubah dengan lebih jelas selepas era kemerdekaan. Sebagaimana yang telah dinyatakan, pada peringkat awalnya, majoriti wanita tertumpu dalam sektor pertanian. Malah ketika itu, jumlah wanita yang menjadi suri rumah tangga sepenuh masa juga tinggi ekoran pertambahan saiz keluarga, kurang pengetahuan untuk terlibat dalam pekerjaan luar sektor pertanian. ${ }^{77}$ Namun kini, jumlah penglibatan wanita dalam sektor ekonomi semasa meningkat semakin tinggi ekoran ruang dan peluang pendidikan yang lebih baik. Perubahan ini turut memberi implikasi hukum yang mana mereka tidak lagi tertumpu dalam dunia rumahtangga sepenuhnya, sebaliknya lebih terbuka penyertaan mereka dalam sektor ekonomi.

\footnotetext{
${ }^{68}$ Fatimah (1985), "Wanita Dan Pekerjaan," h. 84.

${ }^{69}$ Anthony Reid (1988), Southeast Asia in the Age of Commerce 1450-1680: Volume One the Lands Below the Winds, New Haven: Yale University Press, h. 162-172.

${ }^{70}$ Kassim Ahmad (ed.) (1981), Kisah Pelayaran Abdullah ke Kelantan dan ke Judah, Kuala Lumpur: Fajar Bakti, h. 56.

${ }^{71}$ Maila Stivens (1996), Matriliny and Modernity: Sexual Politics and Social Change in Rural Malaysia, Victoria: Allen \& Unwin, h. 75.

${ }^{72}$ Swift (1965), Malay Peasant Society in Jelebu, h. 71.

${ }^{73}$ Rosemary Firth (1966), Housekeeping Among Malay Peasants, Ed. Ke-2, New York: The Athlone Press, h. 26.

${ }^{74}$ Nor Aini Haji Idris (2008), Wanita dan Pembangunan Ekonomi, Kuala Lumpur: Dewan Bahasa \& Pustaka, h. 16.

${ }^{75}$ Nor Aini (2008), Wanita dan Pembangunan Ekonomi, h. 16.

${ }^{76}$ Nor Aini (2008), Wanita dan Pembangunan Ekonomi, h. 16.

${ }^{77}$ Nor Aini (2008), Wanita dan Pembangunan Ekonomi, h. 38.
} 
Dalam konteks masyarakat Melayu, wanita yang tidak terlibat dengan pekerjaan di luar rumah pula tidak boleh dikatakan tidak terlibat dalam memberi sumbangan terhadap ekonomi rumah tangga. Persepsi ini wujud mungkin kerana terdapatnya diskriminasi yang menganggap kerja-kerja rumah yang dilakukan oleh wanita tidak memberikan sebarang nilai ekonomi. ${ }^{78}$ Mereka mungkin dianggap hanya menjalankan tugas rutin sebagai seorang isteri seperti menjaga anak-anak, membasuh pakaian, memasak, mengemas rumah dan sebagainya yang tidak diberikan "merit" ekonomi. Oleh kerana itulah, kerja rumah tidak diambil kira dalam pengiraan pendapatan negara. ${ }^{79}$

Pada hakikatnya dari segi masa, seorang wanita khususnya suri rumah tangga bekerja lebih lama daripada seorang lelaki. ${ }^{80}$ Bermula seawal sebelum subuh dengan mengejutkan suami dan anak-anak untuk menjalani rutin kehidupan biasa, menyediakan sarapan, membasuh pakaian sehinggalah kepada memastikan anak-anak kembali ke tempat tidur sebagaimana yang sepatutnya. Tugas-tugas rumah tangga ini sebenarnya mempunyai nilai ekonomi yang besar kepada sesebuah keluarga, khususnya membantu suami dan ekonomi keluarga. Dari aspek penjagaan anak-anak yang sering menjadi pertimbangan kaum wanita, ${ }^{81}$ para suami tidak lagi perlu untuk mencari pengasuh bagi menjaga anakanak yang kecil kerana isteri akan berada di rumah dan menjaga anak-anak tersebut tanpa sebarang upah sebagaimana yang diperlukan jika menggunakan khidmat pengasuh. Ini tentunya akan memberi kelebihan kepada ekonomi keluarga dari aspek pengeluaran wang kepada pihak ketiga.

Oleh kerana itulah kaum wanita Melayu khususnya di Malaysia memainkan peranan yang cukup besar dalam perkembangan ekonomi rumah tangga. Peranan mereka tidak hanya terhad kepada tugas sebagai suri rumah tangga, bahkan menjangkau kepada tugas-tugas lain di lapangan masyarakat. Keadaan ini bukan merupakan satu budaya baru, bahkan telah diwarisi sejak dahulu lagi. Penyertaan mereka yang begitu aktif mungkin disebabkan hak mereka untuk memiliki hartanah mengikut adat Melayu sejak dahulu lagi. ${ }^{82}$ Sejarah telah merakamkan bahawa tiada halangan untuk kaum wanita Melayu melakukan aktiviti ekonomi di luar rumah, mahupun di dalam rumah yang akhirnya membawa kepada pengiktirafan sejarah terhadap hak-hak mereka untuk mendapatkan harta sepencarian.

\section{Elemen Sumbangan dalam Pembahagian Harta Sepencarian ${ }^{83}$}

Dalam pembahagian harta sepencarian, elemen sumbangan memainkan peranan yang sangat penting dalam penentuan kadar dan hak pihak-pihak dalam pembahagian harta sepencarian. Ini kerana sumbangan lah yang akan menentukan banyak atau sedikitnya kadar yang akan diperolehi pihakpihak dalam setiap tuntutan harta sepencarian yang dikemukakan kepada Mahkamah. Umum juga mengetahui bahawa sumbangan dalam harta sepencarian adalah melibatkan sumbangan langsung dan sumbangan tidak langsung.

Sumbangan langsung yang wujud dalam harta sepencarian merupakan satu elemen yang sangat jarang dipertikaikan. Ini kerana apabila wujudnya keterangan yang membuktikan wujudnya sumbangan langsung daripada pihak isteri, maka keterangan tersebut sudah memadai bagi mahkamah untuk membuat perintah yang berkaitan dengan sumbangan langsung ini. Sumbangan langsung juga dikenali sebagai sumbangan bersama di mana kedua-dua pihak mempunyai sumbangan masingmasing dalam memperolehi sesuatu harta. Dengan kata lain, sumbangan langsung wujud apabila suami dan isteri sama-sama bekerja atau berusaha bagi mendapatkan pemilikan sesuatu harta atau aset seperti pembelian sebidang tanah. Ini bermakna kedua-dua pihak menyumbang modal dan usaha ke arah memperolehi harta tersebut. ${ }^{84}$

\footnotetext{
${ }^{78}$ Nor Aini (2008), Wanita dan Pembangunan Ekonomi, h. 69.

${ }^{79}$ Nor Aini (2008), Wanita dan Pembangunan Ekonomi, h. 69.

${ }^{80}$ Nor Aini (2008), Wanita dan Pembangunan Ekonomi, h. 69.

${ }^{81}$ Nor Aini (2008), Wanita dan Pembangunan Ekonomi, h. 69.

82 Jamilah Ariffin (2003), "Sejarah Pembangunan Malaysia dan Perubahan Peranan Wanita-Dari Sudut Ekonomi dan Pendidikan," dalam Siti Fatimah Abdul Rahman (ed.), Pemartabatan Wanita Di Malaysia, Kuala Lumpur: Institut Kefahaman Islam Malaysia, h. 13.

${ }^{83}$ Rujukan lanjut sila lihat Mohd Anuar Ramli, Mohd Norhusairi Mat Hussin dan Mohd Aizat Jamaluddin (2012), "Elemen Sumbangan Dalam Pembahagian Harta Sepencarian: Pengalaman Kaum Wanita Melayu Di Malaysia,” ESTEEM Academic Journal, Jil. 8, Bil. 2, h. 7792.

${ }^{84}$ Muhammad Asri Abdullah (2001), Tarbiah Kekeluargaan Islam, Perak: Jabatan Kehakiman Syariah Perak, h.43.
} 
Dalam kes yang popular ialah kes Roberts lwn Umi Kalthom. ${ }^{85}$ Kedua-dua suami dan isteri ini bekerja dan mereka berkongsi membeli sebuah rumah di Kuala Lumpur dengan harga RM 50000. Suami telah mengeluarkan modal sebanyak RM 40000 dan isteri mengeluarkan modal sebanyak RM 10000. Memandangkan suami pada masa itu merupakan pegawai kerajaan, maka rumah tersebut telah didaftarkan di atas nama isteri. Apabila berlaku perceraian, suami telah mencadangkan supaya hartaharta yang diperolehi tersebut dibahagi dua tetapi telah dibantah oleh isteri. Suami kemudiannya telah memfailkan permohonan ke Mahkamah Tinggi Sivil bagi menuntut harta tersebut.Yang Arif Raja Azlan Syah yang merupakan hakim pada waktu itu telah memutuskan bahawa harta tersebut merupakan harta sepencarian dan dengan persetujuan kedua-dua belah pihak harta itu telah dibahagi sama rata antara mereka. ${ }^{86}$ Meskipun di dalam kes ini, pihak-pihak telah bersetuju untuk membahagikan harta tersebut kepada dua, tetapi ianya jelas menunjukkan bahawa sumbangan langsung khususnya dalam bentuk kewangan merupakan faktor penting pembahagian sama banyak harta di dalam kes ini.

Dalam aspek sumbangan tidak langsung khususnya bagi isteri yang tidak bekerja, terdapat beberapa kadar pembahagian seperti $1 / 2,1 / 3,1 / 4$, dan $2 / 3$, bergantung kepada takat sumbangan tidak langsung yang diberikan. Biasanya wanita tetap memainkan peranan yang penting kepada sesebuah institusi kekeluargaan sebagaimana yang telah dihuraikan sebelum ini. Oleh yang demikian, undang-undang telah mengiktiraf peranan yang dimainkan oleh wanita ini, seterusnya turut memberikan hak kepada kaum wanita dalam memperolehi hak dalam harta sepencarian. Sebagai contoh, sepasang suami isteri yang berasal dari golongan yang kurang berada telah diberikan lesen perniagaan. Isteri tidak bekerja tetapi isteri tersebut merupakan isteri yang taat dan menjalankan urusan rumah tangga dengan baik. Berkat dorongan isteri dan keharmonian rumah tangganya, suami telah berjaya menjalankan perniagaan dan menjadi ahli korporat yang berjaya. Kejayaan suami ini secara tidak langsung merupakan sumbangan isterinya kerana isteri tersebut telah memberi kebahagiaan dan perangsang kepada suami dalam mencapai kejayaan tersebut. ${ }^{87}$ Beberapa sumbangan tidak langsung para wanita yang tidak bekerja juga dapat difahami daripada beberapa keputusan mahkamah dalam kes-kes yang pernah diputuskan.

Dalam kes Boto binti Taha lwn Jaafar bin Muhamed ${ }^{88}$ pihak Plaintif merupakan bekas isteri kepada pihak Defendan. Secara ringkasnya dalam kes ini, isteri merupakan seorang pembantu di sebuah kedai kopi sebelum daripada perkahwinan tersebut berlangsung manakala suami bekerja sebagai penjual ikan. Setelah berkahwin, isteri telah berhenti bekerja dan menumpukan perhatian kepada rumah tangga serta membantu suami menjalankan perniagaannya. Perniagaan suami telah berkembang dan suami berjaya mendapatkan beberapa aset seperti membeli rumah tempat mereka tinggal, sekeping tanah, empat buah kapal untuk menangkap ikan serta gerai jual ikan di pasar. Perkahwinan tersebut telah berakhir dengan perceraian pada tahun 1974. Setelah perceraian tersebut, isteri telah memohon untuk mendapatkan harta sepencarian di Mahkamah Tinggi Sivil.

Hakim Salleh Abas dalam kes ini telah memutuskan bahawa usaha isteri menemankan suami dalam menjalankan perniagaan serta telah meninggalkan pekerjaan asalnya selepas berkahwin boleh dikira sebagai bantuan bersama dalam mendapatkan harta tersebut. Dalam kes ini, sungguhpun isteri tidak mengambil bahagian secara langsung dalam perniagaan ikan suaminya, tetapi usaha isteri menemani suami menyebabkan ketenangan fikiran suami yang membolehkannya menguruskan perniagaannya dengan tenang dan berkesan. Dalam kes ini hakim telah memutuskan harta-harta yang diperolehi dalam tempoh perkahwinan mereka adalah harta sepencarian dan dibahagikan sebanyak satu pertiga kepada isteri dan dua pertiga kepada suami.

Selain daripada itu, sumbangan tidak langsung juga terhasil daripada pengaruh isteri yang mampu membantu suami mencapai kejayaan dalam perniagaan atau pekerjaan yang membolehkan suami mendapatkan aset-aset sepanjang perkahwinan. Sebagai contoh, seorang lelaki telah berkahwin dengan seorang wanita dari keturunan yang berpengaruh dan hartawan. Kesan daripada pengaruh keluarga isteri, si suami telah mendapat gelaran tertentu dalam masyarakat dan telah maju dalam perniagaannya. Maka hasil daripada kejayaan tersebut, si suami telah berjaya mengumpulkan banyak

\footnotetext{
85 (1966) 1 MLJ 163.

${ }^{86}$ Ahmad Ibrahim (1999), Undang-Undang Keluarga Islam di Malaysia, Kuala Lumpur: Malayan Law Journal, h. 105

${ }^{87}$ Muhammad Asri (2001), Tarbiah Kekeluargaan Islam, h. 50.

${ }^{88}$ [1984] 5 JH 61.
} 
harta dalam masa perkahwinan mereka itu. Pengumpulan harta tersebut juga merupakan hasil sumbangan tidak langsung isterinya.

Perkara ini dibuktikan dalam kes Tengku Anum Zaharah lwn Dato' Dr Hussein. ${ }^{89}$ Dalam kes ini, plaintif telah membuat tuntutan harta sepencarian iaitu memohon kepada Mahkamah supaya memerintahkan defendan menukar hak milik di atas tanah QT. (M) 81 Lot 6392 Mukim Kapar Kelang seluas tiga ekar kepada Plaintif. Pihak Plaintif dalam kes ini telah dibuktikan tidak memberi apa-apa sumbangan modal untuk mendapatkan harta tersebut, bahkan pihak defendan telah menyumbangkan modal kepada plaintif untuk membuka kedai dan salun rambut. Walau bagaimanapun, Kadi Besar telah berpendapat bahawa isteri telah memberikan sumbangan tidak langsung dengan memberi sokongan kepada perniagaan defendan serta menyebabkan defendan mendapat gelaran Dato'. Gelaran yang diperolehi hasil dengan perkahwinan dengan keluarga Diraja ini telah menyebabkan defendan mendapat kepercayaan orang ramai seterusnya berjaya mengembangkan perniagaannya. Oleh yang demikian, pihak suami atau defendan tidak boleh menafikan sumbangan isteri dalam memperolehi harta tersebut. Maka atas pertimbangan Mahkamah, isteri patut diberi hak dalam harta sepencarian sebagai jaminan hidup di masa akan datang.

Kes ini telah menunjukkan pengiktirafan mahkamah terhadap sumbangan isteri yang tidak bekerja dalam pemerolehan aset perkahwinan. Ini bermakna, seseorang isteri yang menjalankan suri rumah sepenuh masa tidak boleh dianggap tidak memberi apa-apa sumbangan kepada pemerolehan harta dalam perkahwinan. Sumbangan tidak langsung ini juga telah diberikan pengiktirafan undang-undang melalui peruntukan dalam Undang-Undang Keluarga Islam di semua negeri.

Kes-kes Mahkamah yang telah dihuraikan telah menunjukkan bahawa faktor sumbangan sangat memberi kesan kepada hak untuk mendapatkan harta sepencarian. Secara ringkasnya pembahagian elemen sumbangan ini dapat dinyatakan seperti berikut:

Jadual 1: Jenis Sumbangan dalam Harta Sepencarian

\begin{tabular}{|l|l|}
\hline Jenis Sumbangan & \multicolumn{1}{|c|}{ Perkara } \\
\hline \multirow{4}{*}{$\begin{array}{l}\text { Sumbangan } \\
\text { Langsung }\end{array}$} & $\begin{array}{l}\text { 1) Sumbangan dalam bentuk modal (perkongsian modal) dan bantuan } \\
\text { kewangan untuk mendapatkan sesuatu harta. Contohnya isteri memberi } \\
\text { sejumlah wang kepada suami untuk membeli rumah, tanah, saham dan } \\
\text { sebagainya. }\end{array}$ \\
\cline { 2 - 3 } & $\begin{array}{l}\text { 2) Sumbangan dalam bentuk tenaga. Isteri turut sama membantu suami } \\
\text { mengusahakan tanah atau perniagaan suami. }\end{array}$ \\
\hline \multirow{3}{*}{$\begin{array}{l}\text { Sumbangan Tidak } \\
\text { Langsung }\end{array}$} & $\begin{array}{l}\text { 1) Isteri tidak bekerja tetapi merupakan isteri yang taat serta menjalankan } \\
\text { urusan rumah tangga dengan baik sehingga suami dapat menjalankan } \\
\text { pekerjaan dengan tenang dan berjaya. }\end{array}$ \\
\cline { 2 - 2 } & $\begin{array}{l}\text { 2) Isteri merupakan seorang yang berasal daripada keluarga yang } \\
\text { berpengaruh, yang menjadi pemangkin kepada penganugerahan apa-apa } \\
\text { gelaran, projek perniagaan dan sebagainya kepada suami sehingga suami } \\
\text { berjaya dalam perniagaan seterusnya berjaya mengumpulkan aset-aset } \\
\text { semasa perkahwinan. }\end{array}$ \\
\hline
\end{tabular}

Sumber: Analisis Penulis

\section{Harta Sepencarian dalam Undang-Undang Keluarga Islam di Malaysia}

Harta Sepencarian yang diasaskan oleh adat masyarakat Melayu telah mendapat kedudukan yang khusus dalam undang-undang Islam di Malaysia khususnya Undang-Undang Keluarga Islam di semua negeri. Peruntukan berkaitan Harta Sepencarian ini telah dipinda dan ditambahbaik dari semasa ke semasa demi untuk menjaga hak dan keadilan pihak-pihak yang bertikai. Ini dapat dilihat dengan pengemaskinian serta penyelarasan peruntukan Harta Sepencarian yang diperuntukkan dalam Enakmen Undang-undang Keluarga Islam negeri-negeri seluruh Malaysia. Penyelarasan ini selain untuk menambah kecekapan mahkamah, ianya juga dapat membantu untuk mengelakkan kekeliruan masyarakat awam dalam memahami undang-undang di Mahkamah Syariah.

${ }^{89}$ [1980] 3 JH 125. 
Sejarah dan Perkembangan Amalan Pembahagian Harta Sepencarian dalam Masyarakat Islam di Malaysia

Umumnya peruntukan berkaitan dengan Harta Sepencarian dapat dilihat dalam tiga peruntukan iaitu berkaitan dengan tafsiran, peruntukan utama dan peruntukan untuk menegah melupuskan harta yang berkaitan Harta Sepencarian. Kedudukan Harta Sepencarian dalam undang-undang keluarga Islam negeri-negeri yang terkini dapat dilihat contohnya sebagaimana Jadual 2 berikut:

Jadual 2: Akta Undang-Undang Keluarga Islam (Wilayah-Wilayah Persekutuan) (Pindaan) 2006

\begin{tabular}{|c|c|c|}
\hline Seksyen & & Perkara \\
\hline 2 & Tafsiran & $\begin{array}{l}\text { "Harta Sepencarian" ertinya harta yang diperolehi bersama oleh suami } \\
\text { isteri semasa perkahwinan berkuat kuasa mengikut syarat-syarat yang } \\
\text { ditentukan oleh Hukum Syarak; }\end{array}$ \\
\hline 122 & $\begin{array}{l}\text { Pembahagian } \\
\text { Harta } \\
\text { Sepencarian }\end{array}$ & $\begin{array}{l}\text { (1) Mahkamah hendaklah mempunyai kuasa, apabila membenarkan lafaz } \\
\text { talaq atau membuat suatu perintah perceraian, untuk memerintahkan } \\
\text { supaya apa-apa aset yang diperoleh pihak-pihak semasa perkahwinan } \\
\text { mereka melalui usaha bersama mereka dibahagikan antara mereka atau } \\
\text { supaya apa-apa aset itu dijual dan hasil jualan itu dibahagikan antara } \\
\text { pihak-pihak } \\
\text { (2) Pada menjalankan kuasa yang diberikan oleh subseksyen (1), } \\
\text { Mahkamah hendaklah mengambil kira tentang- } \\
\text { a- takat sumbangan yang dibuat oleh setiap pihak dalam bentuk wang, } \\
\text { harta, atau kerja bagi memperoleh aset itu; } \\
\text { b- apa-apa hutang yang belum dijelaskan oleh salah satu pihak yang telah } \\
\text { dilakukan bagi manfaat bersama mereka; dan } \\
\text { c- keperluan anak-anak yang belum dewasa daripada perkahwinan itu, } \\
\text { jika ada, } \\
\text { dan, tertakluk kepada pertimbangan itu, Mahkamah hendaklah membuat } \\
\text { pembahagian yang sama banyak. } \\
\text { (3) Mahkamah hendaklah mempunyai kuasa, apabila membenarkan lafaz } \\
\text { talaq atau membuat suatu perintah perceraian, untuk memerintahkan } \\
\text { supaya apa-apa aset yang diperoleh semasa perkahwinan melalui usaha } \\
\text { satu pihak kepada perkahwinan itu semata-mata dibahagikan antara } \\
\text { pihak-pihak itu atau supaya apa-apa aset itu dijual dan hasil jualan itu } \\
\text { dibahagikan antara pihak-pihak itu. } \\
\text { (4) Pada menjalankan kuasa yang diberikan oleh subseksyen (3), } \\
\text { Mahkamah hendaklah mengambil kira tentang- } \\
\text { a- takat sumbangan yang dibuat oleh pihak yang tidak memperoleh aset } \\
\text { itu kepada kebajikan keluarga dengan memelihara rumahtangga atau } \\
\text { menjaga keluarga; dan } \\
\text { b- keperluan anak-anak yang belum dewasa daripada perkahwinan itu, } \\
\text { jika ada, } \\
\text { dan, tertakluk kepada pertimbangan itu, Mahkamah boleh membahagikan } \\
\text { aset itu atau hasil jualan itu mengikut apa-apa kadar yang difikirkan oleh } \\
\text { Mahkamah sebagai munasabah, tetapi, dalam apa-apa hal, pihak yang } \\
\text { melalui usahanya aset itu telah diperoleh hendaklah menerima kadar yang } \\
\text { lebih besar. } \\
\text { (5) Bagi maksud seksyen ini, sebutan tentang aset yang diperoleh semasa } \\
\text { sesuatu perkahwinan termasuklah aset yang dipunyai oleh satu pihak } \\
\text { sebelum perkahwinan itu yang telah dimajukan sebahagian besarnya } \\
\text { dalam masa perkahwinan itu oleh pihak yang satu lagi atau melalui usaha } \\
\text { bersama mereka.”. }\end{array}$ \\
\hline 107 & Tegahan & $\begin{array}{l}\text { (1) Mahkamah boleh, atas permohonan mana-mana pihak kepada sesuatu } \\
\text { perkahwinan- } \\
\text { a- jika mana-mana prosiding hal ehwal suami isteri masih belum selesai; } \\
\text { atau } \\
\text { b- dalam mana-mana prosiding yang Mahkamah boleh membuat perintah } \\
\text { di bawah seksyen } 122 \text {, } \\
\text { membuat suatu perintah melarang isteri atau suami, mengikut mana-mana } \\
\text { yang berkenaan, daripada melupuskan apa-apa aset yang telah diperoleh }\end{array}$ \\
\hline
\end{tabular}




\begin{tabular}{|l|l|}
\hline & mereka, secara usaha bersama atau usaha satu pihak semata-mata, semasa \\
& perkahwinan mereka berkuat kuasa jika Mahkamah berpuas hati adalah \\
perlu untuk berbuat demikian. & (2) Kegagalan untuk mematuhi perintah yang dibuat di bawah subseksyen \\
(1) boleh dikenakan hukuman sebagai suatu penghinaan kepada \\
Mahkamah.”.
\end{tabular}

Sumber: Akta Undang-Undang Keluarga Islam 1984

Jadual 2 menunjukkan peruntukan-peruntukan mengenai Harta Sepencarian. Sebenarnya ia hampir sama dengan enakmen-enakmen negeri yang lain yang juga mempunyai tiga seksyen utama yang menyentuh tentang Harta Sepencarian. Bahkan kebanyakan negeri mempunyai seksyen dan peruntukan yang hampir sama dengan peruntukan di Wilayah Persekutuan. Ia meliputi tafsiran kepada Harta Sepencarian, perintah pembahagian Harta Sepencarian dan perintah tegahan daripada melupuskan Harta Sepencarian. ${ }^{90}$ Negeri-negeri ini memperuntukkan tafsiran Harta Sepencarian di seksyen 2, seksyen 122 untuk perintah pembahagian Harta Sepencarian dan seksyen 108 untuk perintah tegahan melupuskan Harta Sepencarian dalam Enakmen Undang-undang Keluarga Islam di negeri masing-masing. Negeri Sarawak pula mempunyai sedikit perbezaan dalam memperuntukkan perkara yang berkaitan dengan Harta Sepencarian ini khususnya dari segi seksyen dalam Ordinan Undang-undang Keluarga Islam Sarawak 2001. Perbezaan yang wujud hanyalah dari segi peruntukan seksyen iaitu seksyen 58 bagi perintah pembahagian Harta Sepencarian serta seksyen 111 bagi perintah tegahan melupuskan Harta Sepencarian, sebaliknya tafsiran kepada Harta Sepencarian kekal dalam seksyen 2- seksyen tafsiran. ${ }^{91}$ Berbeza dengan negeri Terengganu yang hanya mempunyai dua peruntukan berkenaan dengan Harta Sepencarian iaitu seksyen 2 bagi tafsiran Harta Sepencarian dan seksyen 57 untuk pembahagian Harta Sepencarian. ${ }^{92}$ Terengganu tidak mempunyai peruntukan tegahan melupuskan Harta Sepencarian dalam enakmen undang-undang keluarga Islamnya.

Walaupun begitu, perbezaan sedikit yang berkaitan dengan Harta Sepencarian dalam Undang-undang Keluarga Islam di Malaysia tidak mencacatkan perlaksanaan terhadap pembahagian Harta Sepencarian ini. Undang-undang yang bertulis ini menjamin pemakaian dan pembahagian Harta Sepencarian terhadap pihak-pihak yang bertikai dalam memastikan hak pihak-pihak terpelihara. Daripada perkembangan perundangan Harta Sepencarian ini, perkembangan yang konstruktif dalam undang-undang keluarga Islam berkaitan dengan Harta Sepencarian ini dapat dilihat. Bermula dengan peruntukan yang samar-samar, dibicarakan di Mahkamah Sivil sehinggalah kepada peruntukan yang lebih jelas, relief yang menghalang pelupusan Harta Sepencarian oleh pihak-pihak serta kuasa untuk membicarakan tuntutan ini menjadi hak eksklusif Mahkamah Syariah seperti yang wujud pada hari ini.

\section{Penutup}

Sejarah telah menunjukkan bahawa harta sepencarian telahpun menjadi sebahagian daripada adat resam orang Melayu di Nusantara khususnya di Malaysia. Ianya merupakan satu keunikan dalam tamadun bangsa Melayu, yang tidak didapati dalam tradisi tamadun bangsa yang lain. Sejarah ini kemudiannya disusuli dengan perkembangan yang berlaku bermula daripada adat resam dan akhirnya menjadi sebahagian daripada undang-undang negara. Perkembangan yang berlaku ini adalah sesuai dengan perubahan dan peredaran dalam masyarakat Melayu dari semasa ke semasa. Ini menunjukkan keunikan adat resam diamalkan di Nusantara yang mempunyai indentiti tersendiri dalam mengangkat sumbangan oleh kaum wanita dan memberi perlindungan hak-hak khususnya kepada wanita. Selain daripada itu, ia juga adalah merupakan satu bentuk pengiktirafan terhadap wanita khususnya sudah sekian lama dipraktiskan yang tidak dapat dinafikan. Inilah antara praktis yang memberikan keharmonian hak dan perlindungan yang sewajarnya dalam masyarakat Melayu.

\footnotetext{
${ }^{90}$ Rujuk Enakmen Undang-undang Keluarga Islam Johor 2003, Enakmen Undang-Undang Keluarga Islam Kedah 2008, Enakmen Undangundang Keluarga Islam Kelantan 2002, Enakmen Undang-Undang Keluarga Islam Melaka 2002, Enakmen Undang-undang Keluarga Islam Negeri Sembilan 2003, Enakmen Undang-undang Keluarga Islam Pahang 2005, Enakmen Undang-undang Keluarga Islam Perak 2004, Enakmen Undang-undang Keluarga Islam Pulau Pinang 2004, Enakmen Undang-Undang Keluarga Islam Perlis 2006, Enakmen Undangundang Keluarga Islam Sabah 2004.

${ }^{91}$ Rujuk Ordinan Undang-undang Keluarga Islam Sarawak 2001.

${ }^{92}$ Rujuk Enakmen Pentadbiran Undang-undang Keluarga Islam Terengganu 1985.
} 


\section{Rujukan}

Abu Hassan Othman (1972), "Struktur famili dan tingkah laku kekeluargaan di Selemak: Satu kajian kes," Jurnal Akademika, Jil. 1.

Ahmad Hidayat Buang (2001), "Keupayaan Wanita untuk Berkontrak Di Dalam Undang-Undang Islam," dalam Raihanah Abdullah (ed.), Wanita dan Perundangan Islam, Selangor: Ilmiah Publishers.

al-Jurjani, 'Ali Muhammad (1405H), al-Ta'rifat, Beirut: Dar al-Kitab al-'Arabi.

Al-Zuhayli, Wahbah (1998), Usul Fiqh al-Islami, Cet. Ke-2, Damsyik: Dar al-Fikr.

Arba'iyah Mohd Noor (2020), "The Transition of Malay Women Role and Contribution in Early $20^{\text {th }}$ Century," Journal of Al-Tamaddun, Jil. 15, Bil. 1.

Faisal @ Ahmad Faisal bin Abdul Hamid (2019), “Sistem Tulisan Jawi Dalam Manuskrip Hikayat Raja Handak MS 172 (1832M)," Journal of Al-Tamaddun, Jil. 14, Bil. 1.

Fatimah Abdullah (1985), "Wanita Dan Pekerjaan: Satu Analisis Konflik Peranan," Jurnal Akademika, Jil. 27.

Firth, Rosemary (1966), Housekeeping Among Malay Peasants, Ed. Ke-2, New York: The Athlone Press.

Hale, A. (1898), "Folklore and The Minangkabau Code in Negeri Sembilan," Journal of the Straits Branch of the Royal Asiatic Society, Jil. 31.

Hooker, M. B. (1976), Personal Laws of Malaysia, Oxford: Oxford University Press.

Jamilah Ariffin (2003), "Sejarah Pembangunan Malaysia dan Perubahan Peranan Wanita-Dari Sudut Ekonomi dan Pendidikan," dalam Siti Fatimah Abdul Rahman (ed.), Pemartabatan Wanita Di Malaysia, Kuala Lumpur: Institut Kefahaman Islam Malaysia.

Jelani Harun (2008), "Kajian Naskhah Undang-Undang Adat Melayu di London," Sari - Jurnal Antarabangsa Alam dan Tamadun Melayu, Jil. 26.

Kamus Dewan, Ed. Ke-3 (2000), Kuala Lumpur: Dewan Bahasa dan Pustaka.

Kamus Hukum Adat (1982), Bandung: Penerbit Alumni.

Kassim Ahmad (ed.) (1981), Kisah Pelayaran Abdullah ke Kelantan dan ke Judah, Kuala Lumpur: Fajar Bakti.

Mahmood Zuhdi Abdul Majid dan Raihanah Abdullah (1989), Undang-Undang Keluarga Islam: Konsep dan Perlaksanaan di Malaysia, Kuala Lumpur: Karya Abazie.

Majalah Ahkam al- 'Adliyyah (1968), Cet. Ke-5, Tahun 1968, Beirut: Matba'ah Sha'ari'.

Mat Saad Abdul Rahman (2007), Undang-Undang Keluarga Islam-Aturan Perkahwinan: Suatu Pendekatan Berdasarkan Amalan Semasa, Petaling Jaya: Intel Media Publication.

Mimi Kamariah Abdul Majid (1999), Family Law In Malaysia, Kuala Lumpur: Malayan Law Journal.

Mohd Akhir Hj. Yaacob (1984), “Harta Sepencarian,” Jurnal Hukum, Jil. 5, Bil. 1.

Mohd Anuar Ramli (2005), "Konsep Masyarakat Melayu Mengenai Hubungan Gender," Jurnal Yadim, Jil. 6. 
Mohd Anuar Ramli, Mohd Norhusairi Mat Hussin dan Mohd Aizat Jamaluddin (2012), "Elemen Sumbangan Dalam Pembahagian Harta Sepencarian: Pengalaman Kaum Wanita Melayu Di Malaysia," ESTEEM Academic Journal, Jil. 8, Bil. 2.

Mohd Norhusairi Mat Hussin (2014), Konsep Sumbangan Dalam Penentuan Pembahagian Harta Sepencarian di Mahkamah Syariah Malaysia:Perspektif Sosio-Perundangan, Tesis Doktor Falsafah, Jabatan Syariah dan Undang-Undang, Akademi Pengajian Islam, Universiti Malaya.

Mohd Norhusairi Mat Hussin dan Mohd Anuar Ramli (2013), "Pengambilkiraan 'Urf dan Adat Masyarakat Setempat: Analisis Terhadap Amalan Harta Sepencarian," dalam Mohd Yacob@Zulkifli, et al. (ed.), Dimensi Penyelidikan Dalam Bidang Pengajian Islam, Kuala Lumpur: Akademi Pengajian Islam, Universiti Malaya.

Mohd Ridzuan Awang (1987), Konsep Undang-Undang Tanah Islam: Pendekatan Perbandingan, Kuala Lumpur: al-Rahmaniah.

Muhamad Abu Zuhrah (1985), Usul al-Fiqh, Kaherah: Dar al-Fikr al-‘Arabi.

Muhammad Asri Abdullah (2001), Tarbiah Kekeluargaan Islam, Perak: Jabatan Kehakiman Syariah Perak.

Muhammad Sa'id Ramadan al-Buti (1966), Dawabit al-Mashlahah fi al-Shariah al-Islamiyyah, Damsyik: al-Maktabah al-Umawiyyah.

Nor Aini Haji Idris (2008), Wanita dan Pembangunan Ekonomi, Kuala Lumpur: Dewan Bahasa \& Pustaka.

Nur Saadah Hamisan@Khair, "Ulasan Buku: Nasaruddin Umar (2003), Teologi Jender: Antara Mitos Dan Teks Kitab Suci," Journal of Al-Tamaddun, Jil. 14, Bil. 1.

Othman Ishak (1982), Hubungan antara Undang-Undang Islam dengan Undang-Undang Adat, Kuala Lumpur: Dewan Bahasa dan Pustaka.

Othman Ishak (1997), Hubungan antara Undang-Undang Islam dengan Undang-Undang Adat, Cet. Ke-2, Kuala Lumpur: Dewan Bahasa dan Pustaka.

Portal Rasmi Kerajaan Negeri Sembilan (t.t.), "Introduction of Adat Perpatih," diakses 3 Februari 2020, http://www.ns.gov.my/en/kerajaan/info-negeri/adat-perpatih.

Raja Rohana Raja Mamat (1991), Peranan dan Status Wanita Melayu di Malaysia: Daripada Perspektif Sosial dan Undang-Undang, Kuala Lumpur: Dewan Bahasa dan Pustaka.

Reid, Anthony (1988), Southeast Asia in the Age of Commerce 1450-1680: Volume One the Lands Below the Winds, New Haven: Yale University Press.

S. H. Surojo Wignjodipura (1971), Pengantar dan Asas-Asas Hukum Adat, Bandung: Penerbit Alumni.

Shaykh Ahmad bin Muhammad Zayn Mustafa Al-Fatani (1377H), al-Fatawa Al-Fataniyyah, Siam: Cetakan Pattani Press.

Stivens, M. (1996), Matriliny and Modernity: Sexual Politics and Social Change in Rural Malaysia, Victoria: Allen \& Unwin.

Suwaid Tapah (1996), "Elemen Sumbangan Dalam Amalan Pembahagian Harta Sepencarian di Malaysia," Monograf Shariah. 
Sejarah dan Perkembangan Amalan Pembahagian Harta Sepencarian dalam Masyarakat Islam di Malaysia Suwaid Tapah (1996), Konsep dan Amalan Harta Sepencarian Orang-Orang Islam di Malaysia, Tesis Doktor Falsafah, Jabatan Pengajian Islam, Fakulti Sastera dan Sosial, Universiti Malaya.

Swift, M. G. (1963), "Man and Women in Malay Society," dalam B. E. Ward (ed.), Women in the New Asia, UNESCO.

Swift, M. G. (1965), Malay Peasant Society in Jelebu, New York: Athlone Press.

Taylor, E. N. (1937), “Malay Family Law,” Journal of the Royal Asiatic Society Malayan Branch, Jil. 1.

Wilson, P. J. (1967), A Malay Village and Malaysia, New Haven: Harf Press.

Yusuf Abdul Azeez, Luqman Zakariyah, Syahirah Abdul Shukor dan Ahmad Zaki Salleh (2016), "Codification of Islamic Family Law in Malaysia: The Contending Legal Intricacies," Journal Science International, Jil. 28, Bil 2.

Zaini Nasuhah (2002), Perceraian:Hak Islam, Kuala Lumpur: Lohprint Sdn. Bhd.

Zaleha Kamaruddin (2000), "Islamic Family Law In Malaysia: An Overview," dalam Zaleha Kamaruddin (ed.), Islamic Family Law Issues, Gombak: IIUM Press. 
Journal of Al-Tamaddun, Vol. 15 (2), 2020, 95-113 